\title{
Information Communication Technology in Rescue of Farming Community during COVID-19 Pandemic- A Case of KVK, Ganjam-I
}

\author{
Rojalin Mallick ${ }^{1}$, Santosh Kumar Samantaray ${ }^{2 *}$, \\ Prasanta Kumar Panda ${ }^{2}$ and Manas Ranjan Behera ${ }^{3}$ \\ ${ }^{I}$ Department of CSA, CET, Bhubaneswar, India \\ ${ }^{2}$ KVK, Ganjam-I, OUAT, India \\ ${ }^{3}$ KVK, Puri, OUAT, India \\ *Corresponding author
}

\section{A B S T R A C T}

\section{Keywords \\ Impact; Advisory Services; Mobile application, COVID-19 \\ Article Info \\ Accepted: \\ 24 July 2020 \\ Available Online: \\ 10 August 2020}

A nationwide lock down was enforced in order to limit the spread of COVID-19 during the month of March 2020. Farmers are the most vulnerable to the Covid-19 pandemic. Majority of the poor people in our state rely on agriculture and allied activities for their livelihoods. Lockdowns - as an effective method of protection from the corona virus - had direct impact on farmers, migrant workers and the agriculture supply chain. At KVK, Ganjam-I, different ICT platforms are in use since long for disseminating the advisories. This study was carried out to examine the effectiveness of the information pertaining to Rice cultivation disseminated through Whats app and text messages during the Lockdown period. For the study 90 respondents (Rice growers=50, In-service Personnel=25 and Input Dealers=15) who are using mobile with Whats app. were selected by following purposive random sampling. The result obtained indicated that messages were having medium level of understanding for large majority $(44 \%)$ of the members of Rice grower category, it was highly understandable for 80 and 53.33 percent respondents of In-service Personnel and Input Dealers category respectively. Messages were Needful \& Timely for 64 percent of the Rice growers category and about 68 and 53.33 percent for In-service Personnel and Input Dealers respectively. As for as applicability of the messages are concerned the messages were fully applicable for about 40 percent of Rice growers category, whereas Medium \& Partially applicability was reported by $16 \& 24$ percent of members respectively. It was also found that message was fully applicable for In-service Personnel (60\%) and Input Dealers (53.33\%). It was found that technology imposes high impact on 58 percent of Rice grower category, whereas 72 percent and 53.33 percent members of In-service Personnel and Input Dealers category reported technology impacted highly on them. A low impact was also reported ranging about $08-20 \%$ of among all categories. Over all it is evident from the study that the messages were effective for the farming community. Use of this type of ICT platforms should be encouraged for better visibility. 


\section{Introduction}

The continuous health emergency around COVID19 has influenced varying backgrounds. Shielding lives of individuals experiencing the sickness as well as the frontline health workers have been the need of countries. Governments have swung into action since the Corona virus attack made an extraordinary circumstance. India announced a three-week across the nation lockdown till mid-April in the initial stage, which was subsequently extended for achieving containment of the infection (1). Farmers are the most vulnerable to the Covid-19 pandemic. Majority of the poor people in our state rely on agriculture and allied activities for their livelihoods. Lockdowns - as an effective method of protection from the corona virus - had direct impact on farmers, migrant workers and the agriculture supply chain. With the spread of COVID-19, farmers in Odisha are now exposed to new major challenges. The most alarming challenge is its immediate negative impact on farming activities that is bringing about a new economic and political order in its wake.

Lockdown of rural and urban areas as a first preventive measure against COVID-19 contributes to a drop in the demand for daily consumption of agricultural and livestock produce. In a state like Odisha, food demand depends on people's earnings and so fewer earning opportunities impact consumption. Consequently, if the lockdown continues for a longer period there will be less production in the coming season. Farmers are the economically most affected community under the COVID-19 crisis. This crisis has clearly exposed the vulnerability of States' farm families and farming communities to economic and emotional shocks. Health concerns, home quarantine, financial implications, change in lifestyles have also sent a mental shock to many people. Farmers, are already stressed have been facing an unprecedented crisis which may last for a long time. It pains our hearts when we hear many labourers saying, "Hunger may kill us before corona".

During these difficult times, how does the States' agriculture react to the emergency and how do government initiatives influence farm families across the state of Odisha and thereafter impact the economy of the agrarian state in a developing nation. We assessed the immediate challenges that COVID19 has posed to the farm sector and tried few mitigation measures to ensure a sustainable food system in the post-crisis period.

As the movement, is restricted, we at $\mathrm{KVK}$ level tried to use ICT tools for disseminating the advisories among the farming communities. Web based life and ICT has evolved as one of the most remarkable platforms for trade of correspondence and technology dissemination. In present situation farming being exceptionally important sector which require skill and technical competence (2). Information and Communication Technology (ICT) enabled services have been increasingly advocated by extension practitioners as an alternative to conventional face-to-face extension approaches (3). Online networking is playing a crucial role in development. Different Online networking platforms, for example, Facebook, Twitter, You tube, Whats App, Google meet, Zoom app, Voice messages, text messages and so on are turning out to be more noteworthy methods of sharing information about agricultural technology now a days (4). At KVK, Ganjam-I, we have been using these platforms since long for disseminating the advisories. In this study, we tried to examine the effectiveness of the information disseminated through Whats app and text messages. 


\section{Materials and Methods}

A nationwide lock down was enforced in order to limit the spread of COVID-19 during the month of March 2020. The farmers are the sufferers during this period. They are in dilemma, how to get prepared for the ensuing kharif season. In Ganjam district of Odisha, during kharif season the major crop is Rice. The total area under kharif Rice in Ganjam district is around 2.51 lakh ha. Keeping this background in mind KVK, Ganjam-I has tried to disseminate different useful messages with small video clips pertaining to Rice cultivation through Whats app.

For the study 90 respondents (Rice growers $=50$, In-service Personnel $=25$ and Input Dealers $=15$ ) who are using mobile with Whats app. were selected by following purposive random sampling, from 3 blocks i.e. Surada, Jagannathprasad and Dharakote. These three blocks were selected purposively because, in these blocks more than 70 per cent transplanting operation was over. To assess the overall impact of technology an interview schedule was developed and responses of the respondents were collected over phone call on a four-point continuum scale for each aspect and assigned a scores like-

i. Understandability of the Message (High-3, Medium- 2, Low-1, Not-0),

ii. Need and Time Based Information (Needful \& Timely-3, Needful \& Not Timely2 , Not Needful \& Timely-1, Not Needful \& Not Timely-0) and

iii. Applicability of Message (Fully-3, Medium-2, Partially -1, Not-0). Finally, an index was worked out to assess the overall impact of technology with the help of following equations.
$T I=\frac{O}{S} \times 100$

Where,

$\mathrm{TI}=$ Technology impact index of a respondent

$\mathrm{O}=$ Total scores obtained by respondent

$\mathrm{S}=$ Total obtainable score

\section{Results and Discussion}

Among three categories (Rice growers, Inservice Personnel and Input Dealers), a case study was undertaken to document the impact of services provided to the members and find out their satisfaction with Whats app. services.

\section{Understandability of the Message}

The result obtained in Table 1, indicated that messages were having medium level of understandability for large majority $(44 \%)$ of the members of Rice grower category, it was highly understandable for 80 per cent and 53.33 per cent of In-service Personnel and Input Dealers category respectively. No members of any category were reported that message was not understandable for them. These findings were similar to findings reported by Kanavi et al., (5) and Haradevinder et al., (4)

\section{Need and Time Based Information}

Messages provided on different aspects of Rice cultivation i.e. soil test, appropriate variety, land preparation, seed treatment, raising of seedlings, sowing methods, nursery management, nutrient management, weed management etc. but needfulness and timeliness of the messages was very important. Information must be relevant and meaningful to farmers, in addition to being packaged and delivered in a way preferred by them (6). 
Table.1 Distribution of the Respondents according to understanding of the message

\begin{tabular}{|c|c|c|c|c|c|c|}
\hline \multirow[t]{2}{*}{ Particulars } & \multicolumn{2}{|c|}{$\begin{array}{l}\text { Rice growers } \\
\qquad(\mathrm{n}=\mathbf{5 0})\end{array}$} & \multicolumn{2}{|c|}{$\begin{array}{c}\text { In-service } \\
\text { Personnel }(n=25)\end{array}$} & \multicolumn{2}{|c|}{$\begin{array}{c}\text { Input Dealers } \\
(n=15)\end{array}$} \\
\hline & No. & $\%$ & No. & $\%$ & No. & $\%$ \\
\hline Highly Understandable & 20 & 40 & 20 & 80 & 08 & 53.33 \\
\hline Medium Understandable & 22 & 44 & 05 & 20 & 04 & 26.67 \\
\hline Low Understandable & 08 & 16 & 00 & 00 & 03 & 20.00 \\
\hline Not Understandable & 00 & 00 & 00 & 00 & 00 & 00.00 \\
\hline
\end{tabular}

Table.2 Distribution of the Respondents according to Need and Time Based Information

\begin{tabular}{|l|l|l|c|c|c|c|}
\hline \multicolumn{1}{|c|}{ Particulars } & \multicolumn{2}{|c|}{ Rice growers $(\mathbf{n = 5 0})$} & \multicolumn{2}{c|}{$\begin{array}{c}\text { In-service Personnel } \\
(\mathbf{n = 2 5})\end{array}$} & \multicolumn{2}{c|}{$\begin{array}{c}\text { Input Dealers } \\
(\mathbf{n = 1 5})\end{array}$} \\
\hline & No. & \% & No. & \% & No. & \% \\
\hline Needful \& Timely & 32 & 64.00 & 17 & 68.00 & 08 & $\mathbf{5 3 . 3 3}$ \\
\hline Needful \& Not Timely & 08 & 16.00 & 05 & 20.00 & 03 & $\mathbf{2 0 . 0 0}$ \\
\hline Not Needful \& Timely & 06 & 12.00 & 03 & 12.00 & 03 & $\mathbf{2 0 . 0 0}$ \\
\hline $\begin{array}{l}\text { Not Needful \& Not } \\
\text { Timely }\end{array}$ & $\mathbf{0 4}$ & $\mathbf{0 8 . 0 0}$ & $\mathbf{0 0}$ & $\mathbf{0 0 . 0 0}$ & $\mathbf{0 1}$ & $\mathbf{0 6 . 6 7}$ \\
\hline
\end{tabular}

Table.3 Distribution of the Respondents according to Applicability of Message

\begin{tabular}{|l|l|l|c|c|c|c|}
\hline \multicolumn{1}{|c|}{ Particulars } & \multicolumn{2}{|c|}{ Rice growers $(\mathbf{n = 5 0}$} & \multicolumn{2}{c|}{$\begin{array}{c}\text { In-service Personnel } \\
(\mathbf{n = 2 5})\end{array}$} & \multicolumn{2}{c|}{$\begin{array}{c}\text { Input Dealers } \\
(\mathbf{n = 1 5})\end{array}$} \\
\hline & No. & \% & No. & \% & No. & \% \\
\hline Fully Applicable & 20 & 40.00 & 15 & 60.00 & 08 & $\mathbf{5 3 . 3 3}$ \\
\hline Medium Applicable & 08 & 16.00 & 05 & 20.00 & 03 & $\mathbf{2 0 . 0 0}$ \\
\hline Partially Applicable & 12 & 24.00 & 03 & 12.00 & 04 & $\mathbf{2 6 . 6 7}$ \\
\hline Not Applicable & $\mathbf{1 0}$ & $\mathbf{2 0 . 0 0}$ & $\mathbf{0 2}$ & $\mathbf{0 8 . 0 0}$ & $\mathbf{0 0}$ & $\mathbf{0 0 . 0 0}$ \\
\hline
\end{tabular}

Table.4 Distribution of the Respondents according to Overall Impact of Technology

\begin{tabular}{|c|c|c|c|c|c|c|}
\hline \multirow[t]{2}{*}{ Particulars } & \multicolumn{2}{|c|}{$\begin{array}{l}\text { Rice growers } \\
\qquad(\mathbf{n}=\mathbf{5 0})\end{array}$} & \multicolumn{2}{|c|}{$\begin{array}{l}\text { In-service Personnel } \\
(\mathbf{n}=25)\end{array}$} & \multicolumn{2}{|c|}{$\begin{array}{c}\text { Input Dealers } \\
(n=15)\end{array}$} \\
\hline & No. & $\%$ & No. & $\%$ & No. & $\%$ \\
\hline Low (Score Upto 1-3) & 09 & 18.00 & 02 & 08.00 & 03 & 20.00 \\
\hline Medium (Score Upto 3.1-6) & 12 & 24.00 & 05 & 20.00 & 04 & 26.67 \\
\hline High (Score Upto 6.1-9) & 29 & 58.00 & 18 & 72.00 & 08 & 53.33 \\
\hline
\end{tabular}

The data presented in Table 2 indicated that message was needful and timely for 64 percent of the respondents of Rice growers category and about 68 and 53.33 percent for
In-service Personnel and Input Dealers respectively. Whereas around 12 per cent each from Rice growers, In-service personnel category and 20 per cent Input- dealers 
reported the messages' were not needful but timely delivered. Quite a less numbers of farmers $(08 \%)$, In-service personnel $(00 \%)$ and Input dealers $(6.67 \%)$ were reported the massage was Not Needful \& Not Timely for them.

\section{Applicability of message}

As far as applicability of the messages are concerned the data presented in Table 3 indicates that messages were fully applicable for about 40 percent of Rice grower category, whereas medium \& partially applicable was reported by $16 \& 24$ percent of Rice growers respectively. It was also found that message was fully applicable for In- service Personnel (60\%) and Input Dealers (53.33\%). Medium level of applicability was reported by 20 per cent of members in both In- service Personnel and Input Dealers groups. These findings were similar to findings reported by Kuppuswamy et al., (7) and Kumar et al., (8).

\section{Overall impact of technology}

Table 4 indicated the Overall Impact of Technology and it was found that technology imposes high impact on 58 percent of Rice growers category, whereas 72 percent and 53.33 percent members of In-service Personnel and Input Dealers category reported technology impacted highly on them. A low impact was also reported ranging about 08$20 \%$ of among all categories. Similar results were found by Tayade, et al., (9) Subhashsingh et al., (10) and Kumar et al., (8)

In conclusion the Indian agriculture has drastically changed after LPG (Liberalization, Privatization and Globalization) era. The information given through ICT \& social media is very useful for farming community and timely helpful to solve farmer query through What's app. Farming community accept this technology for gaining technical knowledge for better production. Most of the farmers were satisfied with the use of information sharing app. The results revealed that recommendation of this app should be expanded by the farmers for effective communication between scientists / expertfarmers as well as farmers-farmers. In spite of positive effects there are some problems which were faced by the farmers as they reported many a times they can't use Whats app due to lack of sufficient balance and network connectivity problems in some of the villages. The Whats app service is clearly more than capable of providing timely, relevant and accessible advice and is valued by those who have engaged with it, but there is need to make it more interactive and embed clear monitoring system to ensure the messages reach the intended audience.

\section{References}

1. Chattopadhyay, B.N., 2004. Value Added e- learning for Quality Extension Education, Presented and Published in the Resource Document of the ICAR Sponsered Winter School on "Advanced Extension Strategies for Agricultural Management with Quality Issues" during 17th November to 16th December, 2004 at BCKV, Kalyani, India.

2. Diekmann, F., C. Loibl, \& M. T. Batte. 2009. "The Economics of Agricultural Information: Factors Affecting Commercial Farmers' Information Strategies in Ohio." Review of Agricultural Economics 31 (4): 853-872.

3. Hardevinder, S., Gurdeep, S. and Jagadish, G., 2012. Analysis of Kisan Mobile Advisory Service in South Western Punjab, J. Krishi Vigyan., pp. 14

4. ICRISAT, 2020, Containing COVID19 impacts on Indian Agriculture assessed on

22.07.2020 
https://www.icrisat.org/containingcovid19-impacts-on-indian-agriculture/

5. Kanavi \& Jahagirdar, 2016. Usefulness of Kisan Mobile Advisory Services (KMAS) by the farmers in Dharwad and Gadag district of Karnatak. Journal of Global Communication, Vol. 9, 215-223.

6. Kipkurgat. T, Onyiego. $\mathrm{M}$ and Chemwaina. S, 2016. Impact of social media on agricultural extension in Kenya: a case of kesses district. International Journal of Agricultural Extension and Rural Development Studies Vol.3, No.1, pp.30-36.

7. Kumar. S, Singh SRK, Sharma R.C., 2014. Impact of Kisan Mobile Advisory Service on Transfer of Agricultural Tecnologies, International Journal of Extension Education Vol. 10: 70-72.
8. Kuppuswamy. S, Narayan. P 2010. The impact of Social Networking websites on the education of youth. IJVCSN, vol. 2(1), 67-79.

9. Manoj Dayal (2006). Information Technology - Need of the Hour for Rural Development. Indian Media Studies Journal, 1 (1): July-Dec. 200679

10. Subhashsingh, P., Bharat, M. and Rai, D. P., 2010. Sustainable models of Information Technology for agriculture and rural development. Indian Research Journal of Extension Education, 10(1), 20- 23.

11. Tayade. A, ET AL., 2011. Information \& Communication technology used by the scientists in KVK \& regional research centre, Journal of Global Communication. Vol. 4(1), 16-26.

\section{How to cite this article:}

Rojalin Mallick, Santosh Kumar Samantaray, Prasanta Kumar Panda and Manas Ranjan Behera. 2020. Information Communication Technology in Rescue of Farming Community during COVID-19 Pandemic- A Case of KVK, Ganjam-I. Int.J.Curr.Microbiol.App.Sci. 9(08): 3000-3005. doi: https://doi.org/10.20546/ijcmas.2020.908.338 